\title{
Efficiency of treatments for controlling Trichoderma spp during spawning in cultivation of lignicolous mushrooms
}

\author{
María Belén Colavolpe, Santiago Jaramillo Mejía, Edgardo Albertó \\ Laboratoty of Mycology and Mushroom Cultivation, Instituto de Investigaciones Biotecnológicas/ \\ Instituto Tecnológico de Chascomús, Consejo Nacional de Investigaciones Científicas y Técnicas, \\ Universidad Nacional de San Martín, Provincia de Buenos Aires, Argentina.
}

Submitted: August 21, 2013; Approved: April 17, 2014.

\begin{abstract}
Trichoderma spp is the cause of the green mold disease in mushroom cultivation production. Many disinfection treatments are commonly applied to lignocellulose substrates to prevent contamination. Mushroom growers are usually worried about the contaminations that may occur after these treatments during handling or spawning. The aim of this paper is to estimate the growth of the green mold Trichoderma sp on lignocellulose substrates after different disinfection treatments to know which of them is more effective to avoid contamination during spawning phase. Three different treatments were assayed: sterilization $\left(121^{\circ} \mathrm{C}\right)$, immersion in hot water $\left(60\right.$ and $\left.80^{\circ} \mathrm{C}\right)$, and immersion in alkalinized water. Wheat straw, wheat seeds and Eucalyptus or Populus sawdust were used separately as substrates. After the disinfection treatments, bagged substrates were sprayed with $3 \mathrm{~mL}$ of suspension of conidia of Trichoderma sp $\left(10^{5}\right.$ conidia/mL) and then separately spawned with Pleurotus ostreatus or Gymnopilus pampeanus. The growth of Trichoderma sp was evaluated based on a qualitative scale. Trichoderma sp could not grow on non-sterilized substrates. Immersions in hot water treatments and immersion in alkalinized water were also unfavorable treatments for its growth. Cocultivation with mushrooms favored Trichoderma $s p$ growth. Mushroom cultivation disinfection treatments of lignocellulose substrates influence on the growth of Trichoderma sp when contaminations occur during spawning phase. The immersion in hot water at $60^{\circ} \mathrm{C}$ for $30 \mathrm{~min}$ or in alkalinized water for $36 \mathrm{~h}$, are treatments which better reduced the contaminations with Trichoderma sp during spawning phase for the cultivation of lignicolous species.
\end{abstract}

Key words: Trichoderma sp, Pleurotus ostreatus, Gymnopilus pampeanus, green mold disease.

\section{Introduction}

Trichoderma sp, also known as green mold, is a cellulolytic filamentous fungus, which frequently contaminates mushroom substrates. This fungus is often observed in the early stages of the process, especially during spawning run period, but also during cropping period and causes huge losses in mushrooms crops (Jandaik and Guleria, 1999; Yarma and Vijay, 1996).

Trichoderma spp infection in edible basidiomycetes have been known for a long time (Komon-Zelazowska et al., 2007). An Agaricus green mold disease started in Northern Ireland in 1985 and rapidly spread over farms across Europe and was quickly succeeded by subsequent outbreaks all along Ireland in 1986, in England and Scotland in 1987, in the Netherlands in 1994, in France in 1997 and in Spain in 1998 (Hermosa et al., 1999; Mamoun et al., 2000). This disease also occurred in the United States and Canada (Castle et al., 1998) causing important economic losses. The escalation of green mold evoked extensive research efforts to identify and study the causative agent (Castle et al., 1998; Krupke et al., 2003; Hatvani et al., 2007).

Green mold causes economic losses not only in Agaricus but also in Pleurotus and Lentinula cultivation.

Send correspondence to Edgardo Albertó. Laboratoty of Mycology and Mushroom Cultivation, Instituto de Investigaciones Biotecnológicas/ Instituto Tecnológico de Chascomús, Consejo Nacional de Investigaciones Científicas y Técnicas, Universidad Nacional de San Martín, CC 164. 7130, Chascomús, Provincia de Buenos Aires, Argentina. E-mail: eoalberto@gmail.com, ealberto@intech.gov.ar. 
Sharma and Vijay (Sharma and Vijay, 1996) reported a green mold attack in oyster mushroom in North America. Serious cases of green mold diseases in P. ostreatus in mushroom farms were recently detected in South Korea, Italy, Hungary and Romania (Hatvani et al., 2007). KomónZelazowska, et al. (2007), determined that the causal agents of this disease were two genetically closely related, but phenotypically strongly different, species of Trichoderma, which have been described as Trichoderma pleurotum and Trichoderma pleuroticola. They belong to the Harzianum clade of Hypocrea/Trichoderma which also includes Trichoderma aggressivum, the causative agent of green mold disease of Agaricus. Both species have been found on cultivated Pleurotus and its substratum in Europe, Iran, and South Korea, but $T$. pleuroticola has also been isolated from soil and wood in Canada, the United States, Europe, Iran, and New Zealand. T. pleuroticola displays pachybasium-like morphological characteristics typical of its neighbors in the Harzianum clade, whereas T. pleurotum is characterized by a gliocladium-like conidiophore morphology which is uncharacteristic of the Harzianum clade. Different species of Trichoderma sp including T. viridae, T. harzianum and T. polysporum, commonly cause also injury both to mycelia and basidioma of Lentinula edodes (Tokimoto and Komatsu, 1979). Trichoderma sp produces several enzymes involved in degradation of the fungal cell walls that may contain chitinases and glucanases (Sivan and Chet, 1989; Geremia et al., 1993; Ait-Lahsen et al., 2001).

Various treatments are used for the preparation of substrate for mushroom cultivation to eliminate competitive fungi. They are: steam sterilization, steam pasteurization, hot water immersion and chemical treatment (Jaramillo and Albertó, 2013); but they are not always successful. Contaminations according to mushroom growers may even occur sporadically after these treatments during handling or spawning. The purpose of this paper is to estimate the growth of the green mold Trichoderma $s p$ on lignocellulose substrates after different disinfection treatments to know which of them are more effective to avoid contamination during spawning phase.

\section{Materials and Methods}

\section{Strains}

Strains used in this work are conserved in ICFC (IIB-INTECH collection of Fungal Cultures, Laboratory of Mycology and Mushroom cultivation, IIB-INTECH; Chascomús, Argentina (reference in the WDCM data base: 826).

\section{Pleurotus ostreatus}

ICFC 153/99, commercial strain, 19-XI-1999, leg. E. Albertó; Gymnopilus pampeanus: ICFC 444/01, Capital Federal, Buenos Aires, Argentina; growing on Eucalyptus,
10-V-2001, leg E. Albertó; ICFC 548/03, Burzaco, Buenos Aires, Argentina, growing on Melia azedarach stalk, 15-11-2003, E. Albertó; Trichoderma sp: ICFC 767/12, Chascomús, Buenos Aires, Argentina; 12-VIII-2012. Leg. M. B. Colavolpe, isolated from P. ostreatus cultivation bag.

\section{Spawn production}

It was prepared following Pieckenstain et al. (1999). Briefly, glass bottles filled with boiled wheat grains and $1 \%$ w/w $\mathrm{CaCO}_{3}$ were sterilized for $1.5 \mathrm{~h}$ at $121^{\circ} \mathrm{C}$, cooled and inoculated with an agar plug ( $1 \mathrm{~cm}$ diam.) cut from the advancing margin of a 5-d-old colony grown on PDA (potato dextrose agar). Bottles were incubated in the dark, at $25^{\circ} \mathrm{C}$, with periodical shaking, during 15 days for Pleurotus and Trichoderma sp, and 30 days for Gymnopilus.

\section{Trichoderma sp inoculum}

Conidia of Trichoderma $s p$ were massively produced using the spawn method. When spawning run period was finished, colonized bottles were left near a window at room temperature until the grains became all green colored due to the mature conidia. A suspension of Trichoderma $s p$ conidia in distilled water was prepared. Colonized grains were immersed in distilled water under laminar flow; conidia were released by shaking. Then, water was filtered using cheesecloth and dropped into an Erlenmeyer flask. Concentration of conidia was adjusted to $10^{5}$ conidia $/ \mathrm{mL}$ using a Neubauer chamber. Conidia suspension was not stored; a new suspension was made evey time it was needed.

\section{Substrate preparation}

Chopped wheat straw, wheat seed, Populus or Eucalyptus sawdust were separately used. Substrates were subjected to different treatments (see next point), then immediately bagged in polypropylene bags $(15 \times 30 \mathrm{~cm})$ containing $100 \mathrm{~g}$ of wet substrate with the addition of $1 \%$ $\mathrm{w} / \mathrm{w}$ of $\mathrm{CaCO}_{3}$. After they reached room temperature, they were sprayed with $3 \mathrm{~mL}$ of water suspension of conidia of Trichoderma sp. per bag and mixed. Then, bags were inoculated with $10 \%$ of spawn of the mushroom used in each experiment $(\mathrm{w} / \mathrm{w})$ and afterwards they were stopped with cotton plugs held by PVC (polyvinyl chloride) cylinders.

\section{Treatments of the substrate}

Different treatments were carried out, 1) immersion in hot water: a thermal bath with automatic temperature regulation was used; substrates were placed during $30 \mathrm{~min}$ into the bath after reaching the temperature of treatment $(60$ or $80{ }^{\circ} \mathrm{C}$ ), then they were drained and put on absorbent papers to adjust the humidity to $70 \%$ and finally bagged: 2) steam sterilization, substrates were firstly bagged, then tap water was added up to $70 \%$ of final humidity and sterilized during $2 \mathrm{~h}$ at $120^{\circ} \mathrm{C}$ at $1.2 \mathrm{psi}$ of pressure; 3) Immersion in alkalinized water: we used the methodology 
proposed by Contreras et al. (2004). Substrates were soaked into an alkaline solution prepared with $0,5 \%$ of calcium oxide for $0,5 \mathrm{~min}, 12 \mathrm{~h}, 24 \mathrm{~h}$ or $36 \mathrm{~h}$.

\section{Experimental design and cultivation conditions}

Three experiments with different objectives were carried out. The first experiment was focused on the evaluation of the growth of the green mold Trichoderma sp after the steam sterilization treatment. Two strains and four different sterilized and non-sterilized substrates were used (Table 1); the following treatments were performed: T (Trichoderma $s p$ spray inoculum), $\mathrm{T}+\mathrm{M}$ (Trichoderma $s p$ spray inoculum + mushroom spawn), and $\mathrm{M}$ (mushroom spawn). Table 1 shows the experimental design. The second experiment was focused on the evaluation of the effect of different temperatures of heat treatments of substrates on the growth of the green mold. Temperatures of $60,80^{\circ} \mathrm{C}$ (direct immersion in hot water) and $120^{\circ} \mathrm{C}$ (steam sterilization of bagged substrates) were assayed. Two strains and three different substrates were used. The following treatments were performed: $\mathrm{T}, \mathrm{T}+\mathrm{M}$ and $\mathrm{M}$ (Table 2). The third experiment was focused on the evaluation of the growth of the green mold after immersion of the substrate in alkalinized water. Wheat straw was immersed in an alkaline solution during four different periods of time: $5 \mathrm{~min}, 12 \mathrm{~h}, 24 \mathrm{~h}$ and 36 h. One strain of Pleurotus ostreatus and one substrate (wheat straw) were used. Three treatments were tested: T, T $+\mathrm{M}$ and $\mathrm{M}$. Controls without inoculating were performed in all experiments, bags were observed after 10 days of incubation at $25{ }^{\circ} \mathrm{C}$ in the dark. Five replicates for all treatments and experiments were carried out. The results were qualitatively expressed by assessing the visual degree of growth and colonization of Trichoderma $s p$. The following symbols indicate degrees of growth of the green mold disease in the bags: $(+)$ : Poor growth, less than $20 \%$ of substrate colonization; $(++)$ : Intermediate growth, $20-50 \%$ of substrate colonization; $(+++)$ : abundant growth, more than $50 \%$ of substrate colonization; (-): non-growth. Figure 1 shows the visual differences in Trichoderma sp growth in the bags with wheat straw substrate spawned with Pleurotus ostreatus and the symbols used.

\section{Results and Discussion}

It is well known that substrate is one of the most important contamination sources for green mold disease, especially if it has a high level of carbohydrates (Fletcher et al., 1986). Different species of Trichoderma can contaminate the substrates; this may be due to the use of different substrates, the origin, and manufacturers (Komon-Zelazowska et al., 2007). Contamination is the result of the inoculum potential plus the ability to rapidly grow in the substrate. The treatments of the substrates are generally used to affect the inoculum potential with the objective of eliminating all the spores of Trichoderma spp present in the substrate, but they do not deal with the colonization ability if a new inoculum is introduced after heat treatment. Arrival of inoculum during spawning is frequent, and in a substrate without competitors, this inoculum may develop rapidly. It is very common for South American mushroom growers to spawn substrate with their hand, without any mechanized help and in absence of care to avoid contamination. Thus, many of the contaminations that bags suffer with Trichoderma sp could occur during spawn phase. To learn more about the conditions that promote Trichoderma $s p$ growth on lignocellulose substrates during spawning phase we designed a number of experiments in which substrates were treated with different methods commonly used to eliminate contaminations and then were inoculated with Trichoderma sp previous to the inoculation with the mushroom spawn. To standardize the experiment, we firstly designed a method to inoculate the substrates with a spray of a suspension of conidia of Trichoderma $s p$. We used two mushroom species: P. ostreatus, widely worldwide cultivated (Lechner and Albertó, 2011) and Gymnopilus pampeanus a species which, at present, is being studied for mushroom production (Colavolpe and Albertó, 2012, 2014). The latter can easily grow on sawdust of Populus and Eucalyptus but not on wheat straw. In our first experiment, results showed that sterilized substrates favor Trichoderma sp growth $(+)$. This result is in agreement with previous works (Velázquez-Cedeño et al., 2004; Velázquez-Cedeño et al., 2006). It is really interesting to observe that T treatment on NS did not produce the growth of

Table 1 - Experimental design to evaluate the growth of green mold disease after sterilization treatment.

\begin{tabular}{|c|c|c|c|c|c|c|}
\hline \multirow{3}{*}{ Substrates } & \multicolumn{6}{|c|}{ Treatments* } \\
\hline & \multicolumn{3}{|c|}{$\mathrm{S}$} & \multicolumn{3}{|c|}{$\mathrm{NS}$} \\
\hline & $\mathrm{T}$ & $\mathrm{T}+\mathrm{M}$ & M & $\mathrm{T}$ & $\mathrm{T}+\mathrm{M}$ & M \\
\hline Wheat straw & $767 / 12$ & $767 / 12+153 / 99$ & $153 / 99$ & $767 / 12$ & $767 / 12+153 / 99$ & $153 / 99$ \\
\hline Wheat seed & $767 / 12$ & $767 / 12+153 / 99$ & $153 / 99$ & $767 / 12$ & $767 / 12+153 / 99$ & $153 / 99$ \\
\hline Populus sawdust & $767 / 12$ & $767 / 12+548 / 03$ & $548 / 03$ & $767 / 12$ & $767 / 12+548 / 03$ & $548 / 03$ \\
\hline Eucalyptus sawdust & $767 / 12$ & $767 / 12+548 / 03$ & $548 / 03$ & $767 / 12$ & $767 / 12+548 / 03$ & $548 / 03$ \\
\hline
\end{tabular}

ICFC strains used: 767/12, Trichoderma sp; 153/99, Pleurotus ostreatus; 548/03, Gymnopilus pampeanus. T: spray of Trichoderma conidia suspension; M: mushroom spawn, S: sterilized substrate, NS: non-sterilized substrate. Five replicates for each test were performed.

*Controls of S and NS treatments without inoculation were also carried out. 


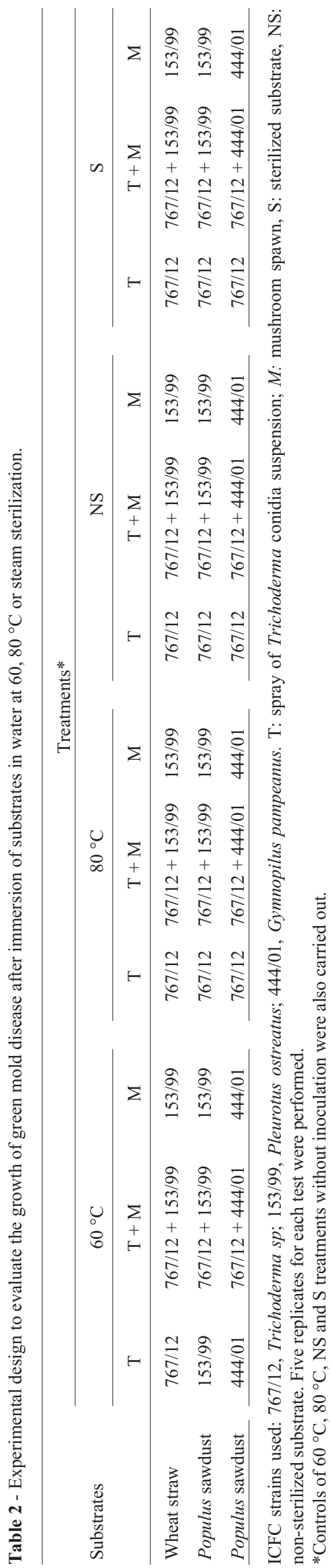

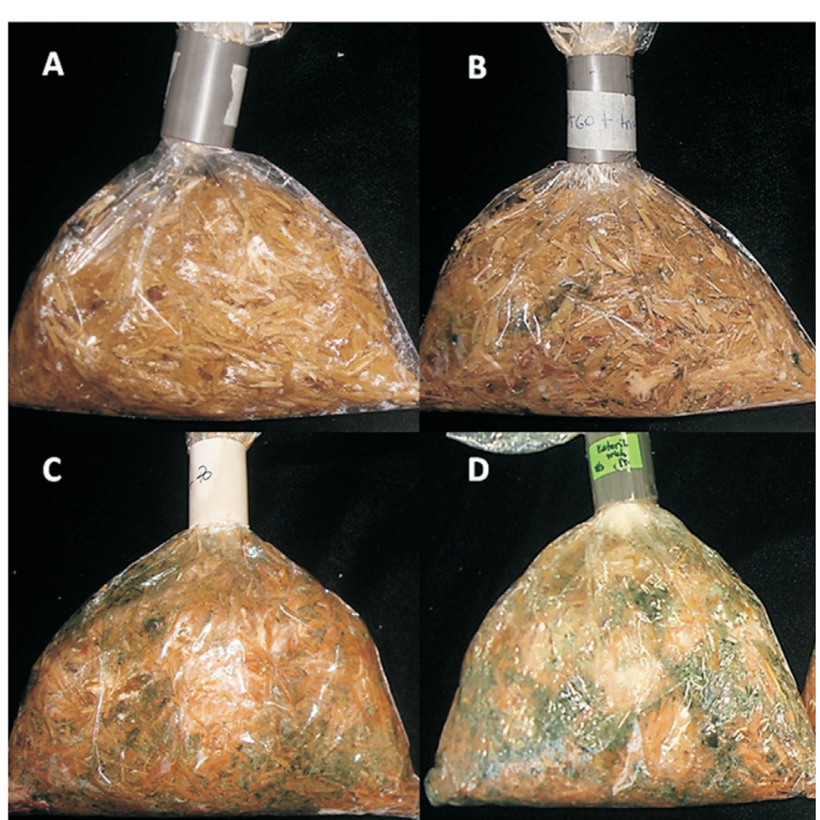

Figure 1 - Growth of Trichoderma $s p$ in the bags: A: (-): non-growth. B: $(+)$ : poor growth, up to $20 \%$ of substrate colonization; $\mathrm{C}:(++)$ : intermediate growth, $20-50 \%$ of substrate colonization; D: $(+++)$ : abundant growth, more than $50 \%$ of substrate colonization.

Trichoderma $s p$ although it had a high concentration of conidia. It is supposed that $\mathrm{S}$ treatment due to high temperature and the cooking effect, released nutrients that benefited the green mold. It is also considered that the reduction of the natural microbial flora of the substrate by the sterilization action increases Trichoderma sp opportunities to colonize the substrate because of a lower presence of competitive micro flora which reduces the possibility of mycelial growth. Bacterial strains can inhibit the growth of Trichoderma $s p$ by production of volatile organic compounds (Mackie and Whetley, 1999) or by releasing antibiotics (Nielsen et al., 2000). Species of bacteria belonging to genus Pseudomonas have been identified as antagonists of Trichoderma sp (Upadhyay et al., 1991; Ellis et al., 2000). Velázquez-Cedeño et al. (2004) proved that the capacity of T. longibrachiatum to compete with P. ostreatus in dual cultures decreased in the presence of other micro-organisms in the substrates. The presence of total microflora increased the production of phenoloxidases by $P$. ostreatus despite a less abundant colonization of the substrate. The production of laccases has already been described as a response to environmental stress (Rayner et al., 1994; Score et al., 1997; Savoie et al., 2001). Velázquez-Cedeño et al. (2007) proved that Bacillus spp. and specifically Paenibacillus polymyxa from cultivation substrates are implicated in their selectivity by both inhibiting the growth of T. harzianum and stimulating defenses' of the mushroom $P$. ostreatus through the induction of laccases.

We used four different substrates to test the growth of Trichoderma $s p$. Wheat straw which is commonly used for 
the production of Pleurotus specie in the region (Carabajal et al., 2012); wheat seed which is used for spawn production, Populus, frequently used for Pleurotus and Shiitake cultivation, and Eucalyptus which is also used for Shiitake (Pire et al., 2001) and Gymnopilus (Colavolpe and Albertó, 2012, 2014). The growth of Trichoderma $s p$ was high $(+++)$ for all substrates for $\mathrm{T}+\mathrm{M}$ treatment with $\mathrm{S}$. No strong differences among substrates and treatments in the growth of Trichoderma $s p$ were observed. Controls were free of contaminants. The source of contaminations in $\mathrm{M}$ treatments is unknown, it was probably present in the susbtrate and could survived due to a not enought sterlization time; for example sawdust (Table 3) in which longer steam treatments are needed.

In a second experiment, the analysis of table 4 also reinforces this hypothesis. In fact, Trichoderma $s p$ did not grow in $60{ }^{\circ} \mathrm{C}, 80^{\circ} \mathrm{C}$ and NS treatments for T treatment. This is a relevant result if we take into account that the concentration of conidia of Thichoderma herein used is high and probably very difficult to find in natural substrates. We also used a high ratio of spawn (10\%), trying to find a balance of forces between the concentration of conidia and the $\%$ of spawn. The lack of contamination of non-treated substrates may occur because of the microbiological quality of the substrate and also due to inability of Trichoderma sp to grow on "non-sterilized substrates" which is probably because of the poor assimilable nutrient availability. Trichoderma sp had difficulty in growing in $\mathrm{M}$ presence; the growth of M may affect some of the antagonistic bacteria present in NS and even thermoresistant ones present in $60{ }^{\circ} \mathrm{C}$, or $80{ }^{\circ} \mathrm{C}$. It is important to remark what happened with $\mathrm{T}+\mathrm{M}$ treatments. In the case of $60{ }^{\circ} \mathrm{C}$ and $80{ }^{\circ} \mathrm{C}$ treatments, Trichoderma sp grew with Pleurotus ostreatus and with Gymnopilus pampeanus, in a smaller proportion than in $\mathrm{S}$ treatments but its growth was very clear. Controls were free of contaminants. We believe that there is an interaction between Trichoderma $s p$ and the mushroom that favors green mold growth. This interaction could be due to the mushroom enzymes action. Enzymes of the mushroom were released to the media and produced an extracellular digestion of the substrate. The nutrients, now available for Trichoderma sp, could be partially absorbed by the fungus and used to colonize the substrate. It is interesting to point out that growth of Trichoderma $s p$ was practically the same at $60^{\circ} \mathrm{C}$ and $80^{\circ} \mathrm{C}$. So, if the mushroom grower uses an immersion in hot water treatment, $60{ }^{\circ} \mathrm{C}$ should be used to save energy and lower production costs. The immersion in hot water has some negative aspects: it uses a great amount of water, which could be a negative factor due to scarcity of this resource in some areas and it produces a reduction in yields due to the loss of nutrients extracted during heating by lixiviation (Jaramillo and Albertó, 2013). Additionally, the use of the alkaline method produces yields that can vary from 37 to $126 \%$ depending on the substrates (Contreras et $a l ., 2004)$ and so is a preferable treatment method.

In the third experiment, we evaluated the growth of Trichoderma sp after the effect of the immersion of the substrate in alkalized water at different immersion times (Table 5). For T treatment, results showed that Trichoderma sp did not grow when period of treatment was 24 or $36 \mathrm{~h}$. Trichoderma $s p$ managed to develop for $\mathrm{T}+\mathrm{M}$ treatment which means that Trichoderma sp could have been benefited by the enzymatic action of mushrooms in the co cultivation. The period of time in which the lower growth $(+)$ was obtained was $36 \mathrm{~h}$. Controls were free of contaminants. Some researchers suggested that adjusting $\mathrm{pH}$ to alkaline levels is a good means of inhibiting the growth of competitor fungi without seriously affecting the growth of $P$. ostreatus (Stölzer and Grabbe, 1991). Contreras et al. (2004) pointed out that no fungal contamination was found in the treated substrates; however certain group of bacteria like pseudomonads, bacilli and coliforms were detected. In this case bacteria action could have also helped to control Trichoderma sp development. For this experience, $M$ treatments grew and colonized the substrate without any difficulty, which means that $\mathrm{pH}$ did not affect mushroom running. From this fact it may be concluded that adjusting $\mathrm{pH}$ by soaking in alkaline solution to alkaline levels is a

Table 3 - Growth of green mold disease after sterilization treatment*.

\begin{tabular}{|c|c|c|c|c|c|c|c|c|}
\hline \multirow{3}{*}{ Substrates } & \multicolumn{8}{|c|}{ Treatments } \\
\hline & \multicolumn{4}{|c|}{$\mathrm{S}$} & \multicolumn{4}{|c|}{ NS } \\
\hline & $\mathrm{T}$ & $\mathrm{T}+\mathrm{M}$ & M & $\mathrm{C}$ & $\mathrm{T}$ & $\mathrm{T}+\mathrm{M}$ & M & $\mathrm{C}$ \\
\hline Wheat straw & $+++(5)$ & $+++(5)$ & $-(5)$ & $-(5)$ & $-(5)$ & $+(5)$ & $+(2)$ & $-(5)$ \\
\hline Wheat seed & $++(5)$ & $+++(5)$ & $-(5)$ & $-(5)$ & $-(5)$ & $-(5)$ & $-(5)$ & $-(5)$ \\
\hline Populus sawdust & $++(5)$ & $+++(5)$ & $+(2)$ & $-(5)$ & $-(5)$ & $-(5)$ & $-(5)$ & $-(5)$ \\
\hline Eucalyptus sawdust & $+(5)$ & $+++(5)$ & $+(1)$ & $-(5)$ & $-(5)$ & $-(5)$ & $-(5)$ & $-(5)$ \\
\hline
\end{tabular}

*See Table 1 for experimental design.

T: Trichoderma sp (ICFC 767/12); T + M: Trichoderma + mushroom spawn (ICFC 153/99 for wheat straw and wheat seed; ICFC 548/03 for Populus and Eucalyptus sawdust), M: Mushroom spawn (ICFC 153/99 for wheat straw and wheat seed; ICFC 548/03 for Populus and Eucalyptus sawdust). S: Sterilized treatment, NS: non-sterilized treatment. C: Control (treatment without inoculation). $(+)$ : poor growth; $(++)$ : intermediate growth; $(+++)$ : abundant growth; (-): non-growth; the number between parentheses indicates number of replicates that obtained the result shown. 

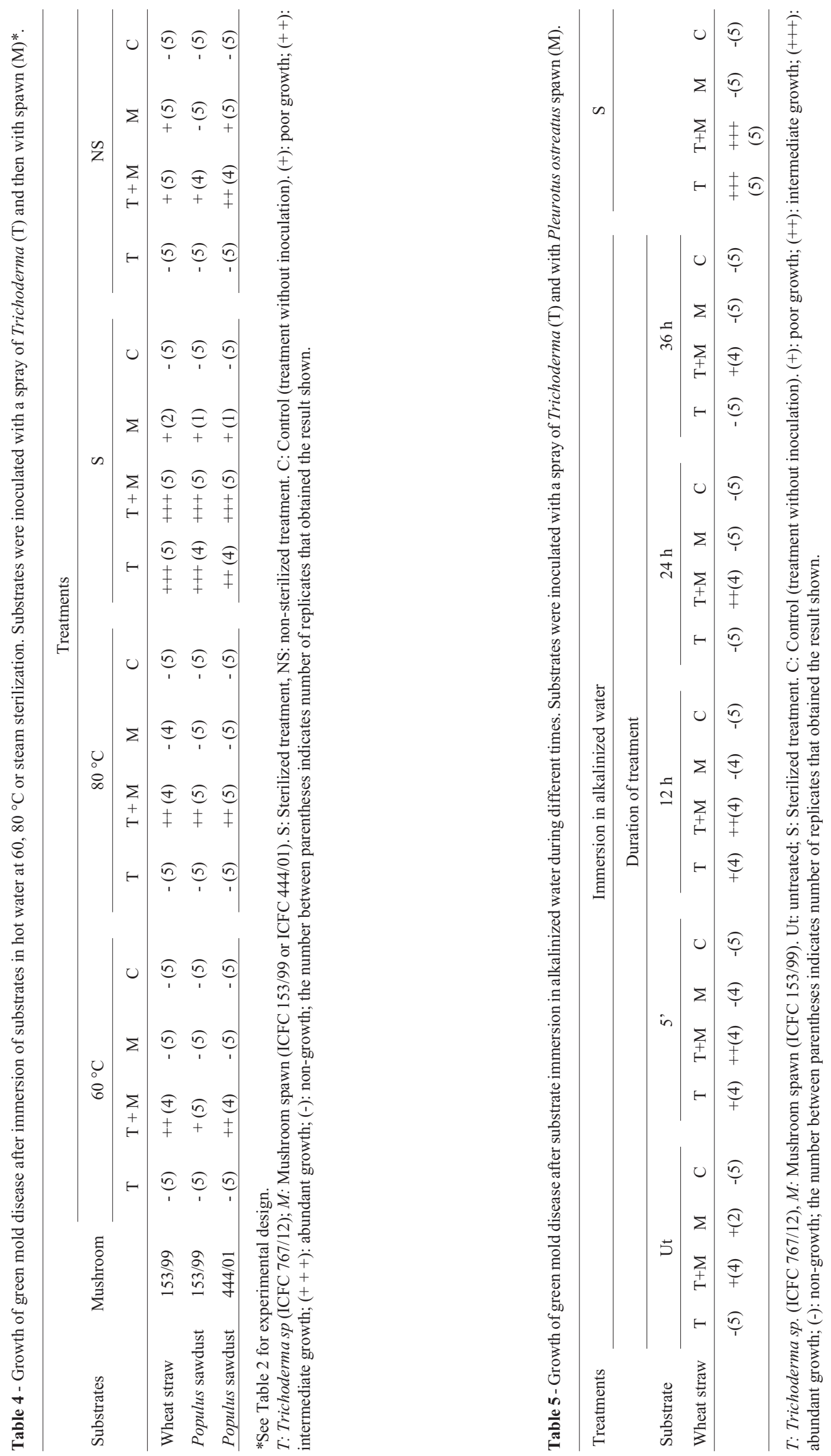
good means of limiting the growth of green mold, and probably other fungi, without seriously affecting the growth of $P$. ostreatus. This confirms reports by Stölzer and Grabbe (1991) and Hernández et al. (Hernández et al., 2003), who suggested the use of alkaline pHs to cultivate this mushroom.

The results here obtained reinforce the hypothesis that mushroom cultivation treatments of the substrates could influence the growth of green mold disease. As a consequence, these treatments would also influence the contamination which may occur during spawning phase. Care for sanitary handling of spawn has to be considered by mushroom farmers. Also, inoculation of bags has to preferably be done in rooms instead of outdoors to avoid contaminations.

Factors that influence Trichoderma sp growth can be summarized as follows: i) the quality of the substrate (microbiological charge of contaminants) before treatment; ii) inability of Trichoderma $s p$ to grow on non-sterilized substrates; iii) reduction of the natural microbial flora by the sterilization action which reduces competition for the substrate; iv) Co- cultivation with mushrooms which promotes Trichoderma $s p$ growth probably by the release of nutrients easily assimilable ( simple sugars); v) Immersion in an alkaline solution limits Trichoderma sp growth.

\section{Conclusion}

Mushroom cultivation disinfection treatments of lignocellulose substrates influence on the growth of green mold disease when contaminations occur during spawning phase. The immersion in hot water at $60{ }^{\circ} \mathrm{C}$ for $30 \mathrm{~min}$ and immersion in alkalinized water for $36 \mathrm{~h}$ are the recommended treatments to avoid contaminations with Trichoderma sp during spawning phase for the cultivation of xylophages species. Care for sanitary handling of spawn has also been considered by mushroom farmers to reduce contaminations. Further studies have to be carried out in order to determine the effects of the treatments on the release or immobilization of readily available nutrients $(\mathrm{C}$ and $\mathrm{N})$ and the development of bacteria by focusing on those able to be antagonists of Trichoderma spp.

\section{Acknowledgments}

This research was made possible by the support of the Argentinian National Research Council (CONICET) and the National University of San Martín (UNSAM).

\section{References}

Ait-Lahsen H, Soler A, Rey M, de La Cruz J, Monte E, Llobell A (2001) An antifungal exo-alpha-1, 3-glucanase (AGN 13.1) from the biocontrol fungus Trichoderma harzianum. Appl Environ Microbiol 67:5833-5839.

Carabajal M, Levin L, Albertó E, Lechner B (2012) Effect of co-cultivation of two Pleurotus species on lignocellulolytic enzyme production and mushroom fructification. International Biodeterioration \& Biodegradation 66(1):71-76.

Castle A, Speranzini D, Rghei N, Alm G, Rinker D, Bissett J (1998) Morphological and molecular identification of Trichoderma $s p$ isolates on North American mushroom farms. Appl Environ Microbiol 64:133-137.

Colavolpe B, Albertó E (2012) Avaliação da produção do cogumelo comestível Gymnopilus espectabilis var pampeanus em serragem de poplar e Eucalyptus. Anales del VII Simposio de Biotecnología Aplicada a la Agricultura. Universidad Paranaense, Umuarama.

Colavolpe, B. Albertó E (2014) Cultivation requirements and substrate degradation of the edible mushroom Gymnopilus pampeanus- a novel species for mushroom cultivation. Scientia Horticulturae 180:161-166.

Contreras EP, Sokolov M, Mejía G, Sánchez JE (2004) Soaking of substrate in alkaline water as a pretreatment for the cultivation of Pleurotus ostreatus. Journal of Horticultural Science and Biotechnology 79(2):234-240.

Ellis RJ, Timms-Wilson TM, Bailey MJ (2000) Identification of conserved traits in fluorescent pseudomonads with antifungal activity. Environ Microbiol 2:274-284.

Fletcher JT, White PF, Gaze RH (1986) Mushrooms: Pest and Disease Control. Intercept Limited, Newcastle, England, $159 \mathrm{pp}$.

Geremia R, Goldman GH, Jacobs D, Ardiles W, Vila SB, Van Montagu M, Herrera-Estrella A (1993) Molecular characterization of the proteinase-encoding gene, prb1, related to mycoparasitism by Trichoderma sp harxiunum. Mol Microbial 8:603-613.

Hatvani L, Antal Z, Manczinger L, Szekeres A, Druzhinina IS, Kubicek CP, Nagy A, Nagy E, Vágvölgyi C, Kredics L (2007) Green mold diseases of Agaricus and Pleurotus spp. are caused by related but phylogenetically different Trichoderma sp species. Phytopathology 97:532-537.

Hermosa MR, Grondona I, Monte E (1999) Isolation of Trichoderma sp harzianum Th2 from commercial mushroom compost in Spain. Plant Dis 83:591.

Hernández D, Sánchez JE, Yamasaki, K (2003) Composting, a simple procedure for preparing substrate for cultivation of Pleurotus ostreatus. Bioresource Technology 90(2):145-50.

Jandaik S, Guleria DS (1999) Yield loss in Agaricus bisporus due to Trichoderma sp infection. Mushroom Res 8:43-46.

Jaramillo S, Albertó E (2013) Heat treatment of wheat straw by immersion in hot water decreases mushroom yield in Pleurotus ostreatus. Rev Iberoam Micol 30(2):125-129.

Komon-Zelazowska M, Bissett J, Zafari D, Hatvani L, Manczinger L, Woo S, Lorito M, Kredics L, Kubicek CP, Druzhinina IS (2007) Genetically closely related but phenotypically divergent Trichoderma $s p$ species causes green mold diseases in oyster mushroom farms worldwide. Applied \& Environmental Microbiology 73(22):7415-7426.

Krupke OA, Castle AJ, Rinker DL (2003) The North American mushrooms competitor, Trichoderma sp aggressivum $\mathrm{f}$. aggressivum, produces antifungal compounds in mushroom compost that inhibit mycelial growth of the commercial mushroom Agaricus bisporus. Mycological Research 107(12):1467-1475.

Lechner BE, Albertó E (2011) Search for new naturally occurring strains of Pleurotus to improve yields. P. albidus as a novel 
proposed species for mushroom production. Rev Iberoam Micol 28:148-154.

Mackie AE, Whetley RE (1999) Effects and incidence of volatile organic compound interactions between soil bacterial and fungal isolates. Soil Biol Biochem 3:375-385.

Mamoun ML, Savoie JM, Olivier JM (2000) Interactions between the pathogen Trichoderma sp harzianum Th2 and Agaricus bisporus in mushroom compost. Mycologia 92:233-240.

Nielsen TH, Thrane C, Christophersen C, Anthoni U, Sorensen J (2000) Structure, production characteristics and fungal antagonism of tensin - A new antifungal cyclic lipopeptide from Pseudomonas fluorescens strain 96.578. J Appl Microbiol 89:992-1001.

Pieckenstain F, Mercuri O, Albertó E (1999) Mevinolin in naturally occurring specimens of Pleurotus cornucopiae. Micol Neotrop Aplicada 12:1-7.

Pire G, Wright JE, Albertó E (2001) Cultivation of shiitake using sawdust of widely available local woods in Argentina. Mic Int Aplic 13(2):1-5.

Rayner ADM, Griffith GS, Wildman HG (1994) Induction of metabolic and morphogenetic changes during mycelial interactions among species of higher fungi. Biochem Soc Trans 22:389-394.

Savoie JM, Mata G, Mamoun M (2001) Variability in brown line formation and intracellular laccase production during interaction between white-rot basidiomycetes and Trichoderma sp harzianum biotype. Mycología 93:243-248.

Score AJ, Palfreyman JW, White NA (1997) Extracellular phenoloxidase and peroxidase enzyme production during interspecific fungal interaction. Int Biodeterior Biodegrad $39: 225-233$.
Sharma SR, Vijay B (1996) Yield loss in Pleurotus ostreatus spp. caused by Trichoderma sp viride. Mushroom Res 5:19-22.

Sivan A, Chet I (1989) Degradation of fungal cell walls by lytic enzymes from Trichoderma sp harzianum. J Gen Microbiol 135:675-682.

Stölzer S, Grabbe K (1991) Mechanisms of substrate selectivity in the cultivation of edible fungi. In: Maher, MJ (ed) Mushroom Science 13. Science and Cultivation of Edible Fungi. Balkema, Rotterdam, pp 141-146.

Tokimoto K, Komatsu M (1979) Effect of carbon and nitrogen sources in media on the hyphal interference between Lentinus edodes and some species of Trichoderma sp. Annals of the Phytopathological Society of Japon 45:261-264.

Upadhyay RS, Visintin L, Jayaswal K (1991) Environmental factors affecting the antagonism of Pseudomonas cepacia against Trichoderma sp viride. Can J Microbiol 37:880-884.

Velázquez-Cedeño M, Farnet AM, Ferre E, Savoie JM (2004) Variation of lignocellulosic activities in dual cultures of Pleurotus ostreatus and Trichoderma sp longibrachiatum on unsterilized wheat straw. Mycologia 96:712-719.

Velázquez-Cedeño MA, Farnet AM, Mata G, Savoie JM (2006) Estudio preliminar de la microflora bacteriana termo tolerante de la pulpa de café y la paja de trigo con potencial de inhibición contra Trichoderma $s p$ viride en el cultivo de Pleurotus. Rev Mex Micol 22:33-39.

Velazquez-Cedeno M, Farnet AM, Mata G and Savoie JM (2007). Role of Bacillus spp. in antagonism between Pleurotus ostreatus and Trichoderma harzianum in heat-treated wheat-straw substrates. Bioresource Technology 99:69666973.

All the content of the journal, except where otherwise noted, is licensed under a Creative Commons License CC BY-NC. 